\title{
Fat-to-glucose interconversion by hydrodynamic transfer of two glyoxylate cycle enzyme genes P Cordero ${ }^{1}$, J Campion ${ }^{1}$, FI Milagro ${ }^{1}$, F Marzo ${ }^{2}$ and JA Martinez*1
}

\author{
Address: ${ }^{1}$ Department of Nutrition and Food Sciences, Physiology and Toxicology, University of Navarra, Pamplona, Spain and ${ }^{2}$ Laboratory of \\ Animal Physiology and Nutrition, School of Agronomy, Public University of Navarra, Pamplona, Spain \\ Email: P Cordero - pcordero@alumni.unav.es; J Campion - jcampion@unav.es; FI Milagro - fmilagro@unav.es; F Marzo - marzo@unavarra.es; \\ JA Martinez* - jalfmtz@unav.es \\ * Corresponding author
}

Published: 10 December 2008

Lipids in Health and Disease 2008, 7:49 doi:10.1186/1476-51IX-7-49

This article is available from: http://www.lipidworld.com/content/7/I/49

(c) 2008 Cordero et al; licensee BioMed Central Ltd.

This is an Open Access article distributed under the terms of the Creative Commons Attribution License (http://creativecommons.org/licenses/by/2.0), which permits unrestricted use, distribution, and reproduction in any medium, provided the original work is properly cited.
Received: 29 September 2008

Accepted: 10 December 2008

\begin{abstract}
The glyoxylate cycle, which is well characterized in higher plants and some microorganisms but not in vertebrates, is able to bypass the citric acid cycle to achieve fat-to-carbohydrate interconversion. In this context, the hydrodynamic transfer of two glyoxylate cycle enzymes, such as isocytrate lyase $(\mathrm{ICL})$ and malate synthase (MS), could accomplish the shift of using fat for the synthesis of glucose. Therefore, 20 mice weighing $23.37 \pm 0.96 \mathrm{~g}$ were hydrodinamically gene transferred by administering into the tail vein a bolus with ICL and MS. After 36 hours, body weight, plasma glucose, respiratory quotient and energy expenditure were measured. The respiratory quotient was increased by gene transfer, which suggests that a higher carbohydrate/lipid ratio is oxidized in such animals. This application could help, if adequate protocols are designed, to induce fat utilization for glucose synthesis, which might be eventually useful to reduce body fat depots in situations of obesity and diabetes.
\end{abstract}

\section{Background}

Thousands of different life-related biochemical processes, such as cell respiration and many other metabolic reactions, can lead to the production and utilization of energy in forms of ATP synthesis and heat release [1-3]. Indeed, all biological processes, including the chemical pathways concerning bioenergetics, follow thermodynamic laws [4].

The central set of reactions involved in cellular fuel homeostasis are collectively known as the citric acid or tricarboxilic acid cycle (TCA cycle), which oxidizes the products of glycolisis and lipid-derived substrates, such as acetyl-CoA, to produce energy in the mitochondria [1]. Indeed, mitochondrial damage and the subsequent dysfunction in this membrane-enclosed organelle are often manifested as neurological disorders, but also as diabetes or obesity [5].

In this context, the glyoxylate cycle is a metabolic pathway well characterized in plants, fungi and several microorganisms [6]. Interestingly, the glyoxylate cycle allows these organisms to use fats for the synthesis of carbohydrates via the acetate generated during fatty acid $\beta$-oxidation, which is achieved by two unique enzymes: isocitrate lyase (ICL; EC 4.1.3.1) and malate synthase (MS; EC 2.3.3.9). These enzymes sequentially catalyse chemical conversions, which are involved in the glyoxylate cycle and appear to be absent or unfunctional in most circumstances in vertebrates, including rodents [7-9], guinea pigs [10] and humans [11]. 
Current gene transfer methodologies are able to incorporate selected nucleotide sequences into the nucleus of target cells $[12,13]$ by means of naked DNA or encoded by molecular constructs named vectors, which can be viral (mainly adeno or retrovirus) or non-viral (lipoplexes, dendromers and others) in order to activate some metabolic linked processes with potential application in gene therapy [14-16].

Considering these findings and observations, our aim was to ascertain the viability of a hydrodynamic gene transfer $[17,18]$ to achieve the heterologous expression of ICL and MS in mouse hepatocytes, in order to produce a bypass in the tricarboxilic acid cycle, enabling the carbons derived from fatty acid oxidation to be preserved and converted into glucose (gluconeogenesis). This approach generating a flow from cell lipid reserves to carbohydrate utilization, can be appropriately assessed after hydrodynamic transfer of two glyoxylate cycle enzyme genes by measuring the respiratory quotient $[19,20]$, as an indicator of the macronutrient mixture oxidized and indirectly the fat-to-glucose conversion.

\section{Methods}

Plasmids. DNA codifying both bacterial enzymes of the glyoxylate cycle (ICL and MS) was obtained from ATCC and both concerned the Vibrio cholearae sequence $\mathrm{gb} /$ AE003852.1/from 01 biovar eltor str N16961 chromosome 1 (clones GVCJA51 for ICL and GVCDP57 for MS). Both clones were subcloned by PCR and inserted in the BssHI restriction enzyme region of the commercial plas$\mathrm{mid} \mathrm{pCMV} / \mathrm{myc} / \mathrm{mito}$ (Invitrogen, USA). Later, they were transformed in Escherichia coli for laboratory scale production using a commercial kit from Qiagen (USA). The plasmid integrity was checked by enzymatic digestion and subsequent agarose gel.

Animals. Twenty male C57BL6J mice (Harlan, Italy) of about 23 g were kept at $21-23^{\circ} \mathrm{C}, 50 \pm 10 \%$ humidity on a 12:12 light-dark cycle (8:00-20:00 h.). After a period of acclimatation of seven days in individual cages, the animals were weighed and assigned to two dietary groups for 36 additional hours: one group $(\mathrm{C}, \mathrm{n}=10)$ received $a d$ libitum commercial food (Harlan Iberica 2014S) containing $349 \mathrm{Kcal} / 100 \mathrm{~g}$ (73\% carbohydrates, 10\% lipids and $17 \%$ protein), and the other group $(\mathrm{F}, \mathrm{n}=10)$ was fasted for the same period. Free water was available at any time in all cages.

Half of the animals assigned to every dietary group randomly received a hydrodynamic load with the control plasmid $\mathrm{pCMV} / \mathrm{myc} /$ mito ( $\mathrm{C}$ and $\mathrm{F}, \mathrm{n}=5$ ) or both plasmids containing the two glyoxylate enzymes (CGx and $\mathrm{FGx}, \mathrm{n}=5$ ). Thus, the mice were administered, in approximately 6 seconds, with a bolus injection in the tail vein with $10 \%$ of their weights $(\mathrm{g})$ in volume $(\mathrm{ml})$ of a complex containing MIRUS polimer solution (Madison, USA) and approximately $20 \mathrm{mg}$ of DNA according to the manufacturer's instructions (MIRUS: MIR-100 trans IT $^{\circledast}$ in vivo gene delivery system) at a constant rate. An equimolar ratio $(2: 1+1 \mathrm{mols})$ was used for administering a bolus containing $\mathrm{pCMV} / \mathrm{myc} / \mathrm{mito}$ or $\mathrm{pCMV} / \mathrm{myc} / \mathrm{mito}-\mathrm{ICL}$ and $\mathrm{pCMV} / \mathrm{myc} / \mathrm{mito}-\mathrm{MS}$ into the animals. The success of the process was assessed by repeating the protocol by measuring $\beta$-galactosidase staining of Lac $Z$ transgene and luciferase activity after CMV-Luc and Lac $Z$ gene hydrodynamic administration in mice under similar conditions [21].

After 36 hours, body weights were carefully measured and final glucose was assessed with a digital glycometer (Medisense Optium, UK) from the jugular vein. The respiratory quotient was measured by using an indirect calorimeter for two hours before the mice were sacrificed. All animal manipulations were made in accordance with European Community Guidelines and University of Navarra Ethical Committee for the use of laboratory animals.

Indirect calorimetry. Oxygen $\left(\mathrm{O}_{2}\right)$ consumption, carbon dioxide $\left(\mathrm{CO}_{2}\right)$ production and respiratory quotient (RQ) were measured using an Oxylet $00 \mathrm{O}_{2} / \mathrm{CO}_{2}$ indirect calorimeter (Panlab SL, Spain) [22] following manufacturer's instructions and using an appropriate software (Chart, ADIntruments, Australia). The $\mathrm{O}_{2}$ and $\mathrm{CO}_{2}$ analyzers were calibrated with highly purified gas standards (Praxair, Spain) and each animal was placed into one of four acrylic chambers $(140 \mathrm{~mm}$ diameter $\times 150 \mathrm{~mm}$ height each $)$. Room air was drawn through each chamber at a rate of $300 \mathrm{~mL} / \mathrm{min}$. The $\mathrm{O}_{2}$ and $\mathrm{CO}_{2}$ levels were then measured on 3-min sampling periods (8 sampling periods per 2 hours of data collection with three chambers) to generate difference scores between data derived from each mouse chamber versus the data collected from room air [22]. RQ was calculated as the ratio of the volume of $\mathrm{CO}_{2}$ produced by the volume of $\mathrm{O}_{2}$ consumed, while energy expenditure was calculated according to the formula $[19,23]$ : EE (kcal/ day $/$ body weight $\left.{ }^{3 / 4}\right)=\mathrm{O}_{2}$ volume $\times 1.44 \times[3.815+(1.232$ $\times \mathrm{RQ})]$.

\section{Results and discussion}

As expected, body weight and plasma glucose measurements were affected by the 36-hour fasting period, being statistically lower in the food-deprived mice (table 1 ). The administration of both plasmids (ICL+MS) or the Control one produced similar changes in both variables (body weight and glycemia) within each nutritional group (control fed or fasted). Energy expenditure values were apparently unaffected by the treatments when they were normalized by body weight. Interestingly, those fasted mice receiving both ICL+MS plasmids showed an 
Table I:

\begin{tabular}{|c|c|c|c|c|c|c|c|}
\hline & \multirow[b]{2}{*}{$C(n=5)$} & \multirow[b]{2}{*}{$F(n=5)$} & \multirow[b]{2}{*}{$C G \times(n=5)$} & \multirow[b]{2}{*}{$F G x(n=5)$} & \multicolumn{3}{|c|}{$2 \times 2$ Anova } \\
\hline & & & & & Nutritional Status & Treatment & Nutritional status $\times$ treatment \\
\hline Weight change (g) & $1.47 \pm 2.59$ & $-4.53 \pm 2.28$ & $0.07 \pm 1.14$ & $-3.33 \pm 1.73$ & $* *$ & n.s. & n.s. \\
\hline Final weight $(\mathrm{g})$ & $24.8 \pm 2.59$ & $18.8 \pm 2.28$ & $23.4 \pm 1.14$ & $20.0 \pm 1.73$ & $* *$ & n.s. & n.s. \\
\hline Glucose (mg/dL) & $112.8 \pm 16.5$ & $75.6 \pm 30.2$ & $122.4 \pm 28.6$ & $69.2 \pm 33.9$ & $* *$ & n.s. & n.s. \\
\hline
\end{tabular}

Means \pm SD of body weight change $(\mathrm{g})$, final weight $(\mathrm{g})$ and plasma glucose $(\mathrm{mg} / \mathrm{dL})$ analized by $2 \times 2$ ANOVA (nutritional status $\times$ treatment). $(\mathrm{C}$; control diet, F; fasting group, C Gx; control diet group with full plasmid, F Gx; fasting group with full plasmid, n.s.; non statistical significance, **; $\mathrm{P}<$ $0.01)$.

increased $(p<0.05)$ respiratory quotient (figure 1$)$ as compared to the fasted control group $(0.76 \pm 0.08$ vs. 0.67 $\pm 0.05)$. This trend was also observed $(p<0.05)$ in the control fed group compared to the ICL+MS plasmidsadministered mice $(0.90 \pm 0.08$ vs. $0.95 \pm 0.04)$ (figure 1$)$.

The results of this experimental trial confirm that hydrodynamic based gene transfer technology is able to increase the $R Q$, which suggests that more glucose is oxidized in relation to lipid utilization $[19,20]$. This finding was especially relevant in the fasting situation, which is interesting because in such conditions lipid reserves are more required for energy expenditure maintenance. The trends in the fed group were also in the same direction, confirming the validity of this gene therapy tool.

The glyoxylate cycle is a critical component of the gluconeogenic machinery responsible for the conversion of acetate into glucose [6]. Indeed, acetate can only serve as a net source of glucose in organisms with the necessary enzymes to catalyze the reactions of the glyoxylate cycle [24]. In this context, ICL and MS are recognized as the pathway specific enzyme activities, while no remaining enzyme activities were in common with activities of the TCA cycle [25].

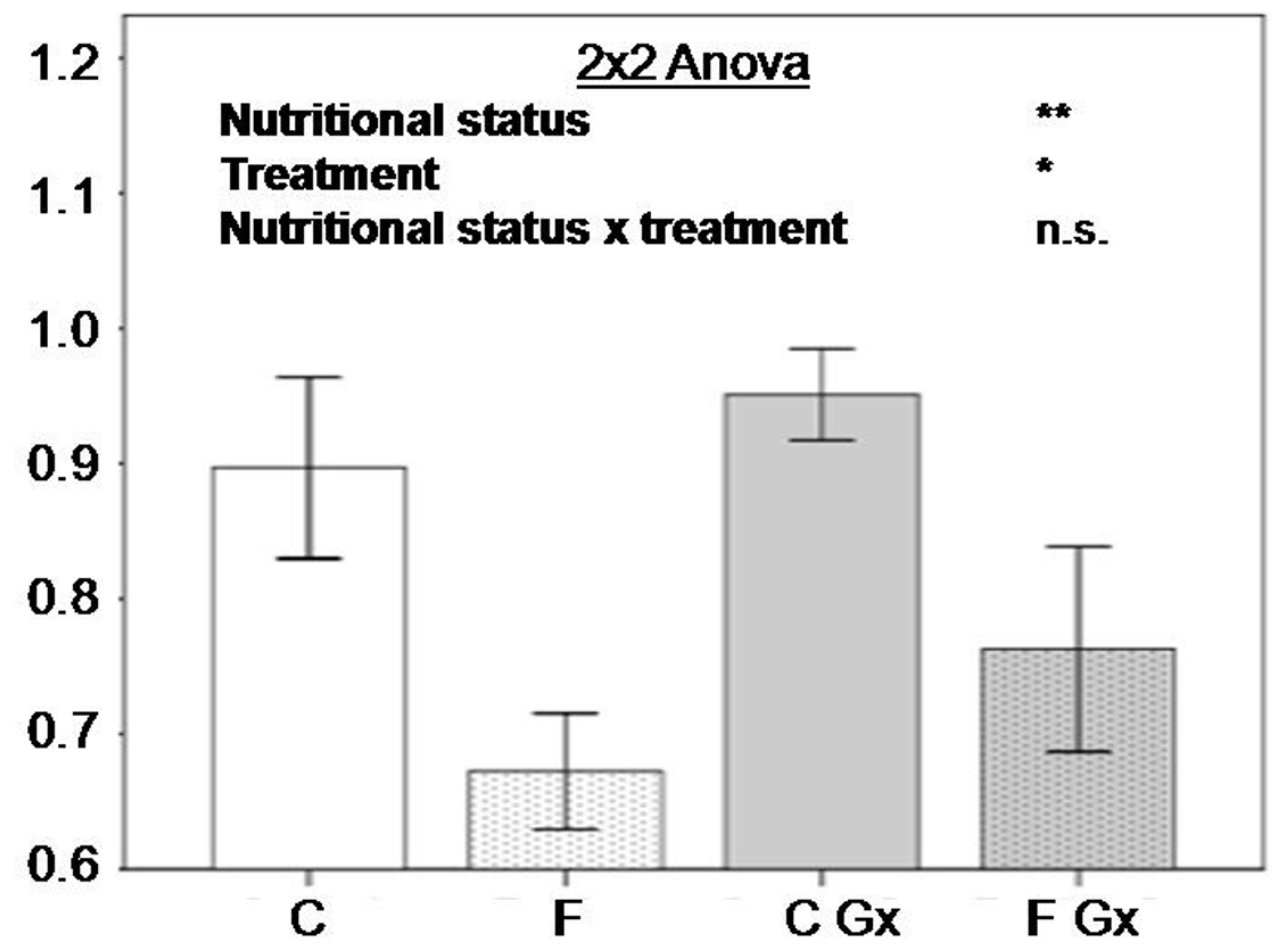

\section{Figure I}

Means \pm SD of respiratory quotient and differences analized by $2 \times 2$ ANOVA (nutritional status $\times$ treatment). (C; control diet, F; fasting group, C Gx; control diet group with full plasmid, F Gx; fasting group with full plasmid, n.s.; non statistical significance, *; $p<0.05, * * ; p<0.01$ ). 
The glyoxylate cycle is well characterized in microorganisms, higher plants [26] and nematods, but the occurrence and functionality in vertebrates, such as rodents, chickens or humans [7-11], is still a matter of debate. This has been attributed to the lack of this metabolic pathway, reduced expression of ICL/MS in normal conditions, or improper induction or measurement of the activity of these enzymes [27].

In this context, our hypothesis was that the presence of a functional glyoxylate cycle might enable the organism to obtain more energy supply from sources different from glucose and facilitate fat mobilization. Strategies based on this approach might accelerate fat utilization in fasting situations or during exercise, increasing thus fuel demands, which might be very useful in obesity and diabetes to reduce adipose tissue depots.

Despite the apparent success of this gene transfer, some aspects and limitations should be taken into account, such as the administered dose, which may affect liver function, as described by others $[17,18]$, the limited number of animals in this translational research or the short period of time analyzed given that fasting can not be maintained at long term [27], among others.

Summing up, this pioneer protocol was able to induce changes in the mechanism of secondary glucose/glycogen production, by the conversion of fat to carbohydrates allowing the net utilization of sugars from acetyl-CoA. This approach, if successfully developed in other species including the human being, could provide a valid gene therapy instrument for obesity and related comorbilities, in which accelerated fat oxidation is required.

\section{Abbreviations}

ICL: Isocytrate lyase; MS: Malate synthase; TCA cycle: Tricarboxilic acid cycle; RQ: Respiratory quotient; ATCC: American type culture collection.

\section{Competing interests}

The authors declare that they have no competing interests.

\section{Authors' contributions}

JC, FIM and JAM conceived and designed the experiments; JC, FIM and PC performed the experiments; PC performed the statistical analyse; JC, FIM, PC, and JAM wrote and edited the manuscript; FM and JAM assumed the economic management.

\section{Acknowledgements}

We would like to thank FJ Novo (Department of Genetics, University of Navarra) for his valuable cloning and scientific assistance, to Chloé Neirynck for her skilfull help in manipulating the animals and Linea Especial from University of Navarra (LE/97) for financial support.

\section{References}

I. Kornberg $\mathrm{H}$ : Krebs and his trinity of cycles. Nat Rev Mol Cell Biol 2000, I (3):225-228.

2. Weber J, Senior AE: ATP synthesis driven by proton transport in FIF0-ATP synthase. FEBS Lett 2003, 545(I):6I-70.

3. González-Muniesa P, Milagro FI, Campión J, Martínez JA: Ectopic UCPI gene expression in HepG 2 cells affects ATP production. I Physiol Biochem 2005, 6 I (2):389-393.

4. Schilstra MJ, Martin SR, Keating SM: Methods for simulating the dynamics of complex biological processes. Methods Cell Biol 2008, 84:807-842.

5. Costford S, Gowing A, Harper ME: Mitochondrial uncoupling as a target in the treatment of obesity. Curr Opin Clin Nutr Metab Care 2007, 10(6):67I-678.

6. Nakazawa M, Minami T, Teramura K, Kumamoto S, Hanato S, Takenaka S, Ueda M, Inui H, Nakano Y, Miyatake K: Molecular characterization of a bifunctional glyoxylate cycle enzyme, malate synthase/isocitrate lyase, in Euglena gracilis. Comp Biochem Physiol B Biochem Mol Biol 2005, I 4I(4):445-452.

7. Popov VN, Igamberdiev AU, Schnarrenberger C, Volvenkin SV: Induction of glyoxylate cycle enzymes in rat liver upon food starvation. FEBS Lett 1996, 390(3):258-260.

8. Popov VN, Volvenkin SV, Eprintsev AT, Igamberdiev AU: Glyoxylate cycle enzymes are present in liver peroxisomes of alloxantreated rats. FEBS Lett 1998, 440(I-2):55-58.

9. Morgunov IG, Kondrashova MN, Kamzolova SV, Sokolov AP, Fedotcheva NI, Finogenova TV: Evidence of the glyoxylate cycle in the liver of newborn rats. Med Sci Monit 2005, I I(2):BR57-60.

10. Jones CT: Is there a gloxylate cycle in the liver of the fetal guinea pig? Biochem Biophys Res Commun 1980, 95(2):849-856.

II. Davis WL, Goodman DB: Evidence for the glyoxylate cycle in human liver. Anat $\operatorname{Rec} 1992,234(4): 461-468$.

12. Weyden L van der, Adams DJ, Bradley A: Tools for targeted manipulation of the mouse genome. Physiol Genomics 2002, II(3): I33-164.

13. Campión J, Milagro Fl, Martínez JA: Genetic manipulation in nutrition, metabolism, and obesity research. Nutr Rev 2004, 62(8):321-330.

14. Marti A, Martinez-Anso E, Zaratiegui M, Aguado M, Martinez JA: Leptin gene transfer into muscle increases lipolysis and oxygen consumption in white fat tissue in ob/ob mice. Biochem Biophys Res Commun 1998, 246(3):859-862.

15. Marti A, Novo FJ, Garcia M, Martinez JA: UCP2 muscle gene transfer modifies mitochondrial membrane potential. Int J Obes Relat Metab Disord 200I, 25(I):68-74.

16. Larrarte E, Novo F], Marti A, Alfredo Martínez J: UCPI muscle gene transfer and mitochondrial proton leak mediated thermogenesis. Arch Biochem Biophys 2002, 404(I):166-17I.

17. Sebestyen MG, Budker VG, Budker T, Subbotin VM, Zhang G, Monahan SD, Lewis DL, Wong SC, Hagstrom JE, Wolff JA: Mechanism of plasmid delivery by hydrodynamic tail vein injection. I. Hepatocyte uptake of various molecules. I Gene Med 2006, 8(7):852-873

18. Budker VG, Subbotin VM, Budker T, Sebestyen MG, Zhang G, Wolff JA: Mechanism of plasmid delivery by hydrodynamic tail vein injection. II. Morphological studies. J Gene Med 2006, 8(7):874-888.

19. Ferrannini E: The theoretical bases of indirect calorimetry: a review. Metabolism 1988, 37(3):287-30।.

20. Tappy L, Schneiter P: Measurement of substrate oxidation in man. Diabetes Metab 1997, 23(5):435-442.

21. Gonzalez-Muniesa P, Milagro FI, Campion J, Martinez JA: Reduction in energy efficiency induced by expression of the uncoupling protein, UCPI, in mouse liver mitochondria. Int $\int \mathrm{Mol}$ Med 2006, I7(4):591-597.

22. Garcia-Diaz DF, Campion J, Milagro FI, Lomba A, Marzo F, Martinez JA: Chronic mild stress induces variations in locomotive behavior and metabolic rates in high fat fed rats. J Physiol Biochem 2007, 63(4):337-346.

23. Weir J: New methods for calculating metabolic rate with special referente to protein metabolism. I Physiol 1949, I09(I2): $1-9$.

24. Lorenz MC: Life and death in a macrophage: role of the glyoxylate cycle in virulence. Eukaryot Cell 2002, I(5):657-662.

25. Schnarrenberger C: Evolution of the enzymes of the citric acid cycle and the glyoxylate cycle of higher plants. A case study 
of endosymbiotic gene transfer. Eur J Biochem 2002, 269(3):868-883.

26. Eastmond PJ, Graham IA: Re-examining the role of the glyoxylate cycle in oilseeds. Trends Plant Sci 200I, 6(2):72-78.

27. Saini KS, Byrne CR, Leish Z, Pruss CA, Rigby NW, Brownlee AG, Nancarrow CD, Ward KA: Introduction and expression of the bacterial glyoxylate cycle genes in transgenic mice. Transgenic Res 1996, 5(6):467-473.

Publish with Bio Med Central and every scientist can read your work free of charge

"BioMed Central will be the most significant development for disseminating the results of biomedical research in our lifetime. " Sir Paul Nurse, Cancer Research UK

Your research papers will be:

- available free of charge to the entire biomedical community

- peer reviewed and published immediately upon acceptance

- cited in PubMed and archived on PubMed Central

- yours - you keep the copyright

Submit your manuscript here:

http://www.biomedcentral.com/info/publishing_adv.asp 